\title{
PEMANFAATAN MODEL BLENDED LEARNING PADA MATA KULIAH DESAIN PEMBELAJARAN BERBASIS KOMPUTER (DPBK)
}

\author{
Ulfia Rahmi
}

\author{
ulfia24@gmail.com
}

\begin{abstract}
The learning process that takes place during this time have not met as mentioned in PP No. 32 tahun 2013, included in the Desain Pembelajaran Berbasis Komputer (DPBK). To fulfill these demands can be done by the utilization of blended learning models. The objective is satisfying student learning outcomes. The method used is descriptive quantitative, which the sample are students who were active in section 25669 in subjects $D P B K$. The results show that the model of blended learning is effective in helping students to understand the material and help them to achieve the desired competencies.
\end{abstract}

Kata kunci: blended learning, model pembelajaran

\section{PENDAHULUAN}

Proses pembelajaran yang berlangsung selama ini belum memenuhi seperti yang disebutkan pada PP nomor 32 tahun 2013. Termasuk pada mata kuliah Desain Pembelajaran Berbasis Komputer (DPBK). DPBK merupakan mata kuliah yang membina kemampuan kognitif dan daya kreativitas/seni mahasiswa dalam merancang suatu materi ajar berdasarkan langkahlangkah dalam merancang satu paket pembelajaran berbasiskan komputer. DPBK terdiri dari beberapa kumpulan dari pengetahuan dan keterampilan dalam mendesain model-model pembelajaran berbasis komputer. Jika merujuk kepada PP nomor 32 tahun 2013, proses pembelajaran pada pelaksanaannya kurang interaktif karena dalam proses pembelajaran tidak terjadi situasi yang diharapkan seperti interaksi. Baik interaksi antara dosen dengan mahasiswa, dosen dengan media yang digunakan, mahasiswa dengan media dan mahasiswa dengan mahasiswa lain serta mahasiswa dengan lingkungan sekitar.

Selama ini kegiatan pembelajaran DPBK dilakukan di laboratorium Program Studi Teknologi Pendidikan dengan jumlah mahasiswa yang relatif banyak sehingga sulit untuk dikontrol. Fasilitas yang tersedia di laboratorium tidak sebanding dengan jumlah mahasiswa yang aktif pada seksi mata kuliah DPBK. Keadaan seperti itu menjadi hambatan dan keterbatasan bagi dosen pembina untuk menyampaikan materi DPBK yang syarat dengan konten kepada mahasiswa. Dengan keadaan seperti itu, dosen pembina memanfaatkan fasiltas kampus seperti internet dengan menghadirkan blog pribadi dalam kegiatan pembelajaran untuk menuntaskan materi yang akan disampaikan. Pada blog tersebut, dosen pembina menyampaikan materi-materi yang dirasa penting, perlu pengulangan, dan tidak sempat disampaikan kepada mahasiswa di 
ruang kelas. Pelaksanaan kegiatan pembelajaran DPBK diselenggarakan dengan memvariasikan penggunaan blog pribadi dosen pembina dalam setiap kegiatan pembelajaran.

Meskipun sudah dilakukan upaya untuk meningkatkan umpan balik dari mahasiswa, dalam proses pembelajaran DPBK selama ini umpan balik dari mahasiswa masih sangat kurang, terlihat dalam kegiatan diskusi yang tidak baik yang mengakibatkan kekurang aktifan dari mahasiswa itu sendiri. Padahal dengan adanya keaktifan dari mahasiwa, kegiatan pembelajaran menjadi lebih interaktif dengan menjadikan kegiatan tersebut menjadi kegiatan yang inspiratif dan menyenangkan serta memotivasi mahasiswa untuk berpartisipasi aktif, sehingga dapat berprakarsa dengan kreatifitas dan kemandirian sesuai dengan bakat dan perkembangan mahasiswa.

Menurut Permendiknas

No. 41 Tahun 2007 tentang Standar Proses mengisyaratkan bahwa dalam proses pembelajaran, seorang pendidik harus dapat memperhatikan karakteristik peserta didiknya. Karakteristiktik mahasiswa sesungguhnya memiliki cakupan yang luas, yaitu gaya belajar, motivasi, pengetahuan awal dan kulturalnya yang akan mempengaruhi terhadap efektivitas belajar dan pembelajaran. Banyak didapati dalam proses pembelajaran karakterisitik mahasiswa tidak terdeteksi satu persatu, sehingga barangkali hal inilah yang menimbulkan kejenuhan pada diri mahasiswa untuk mengikuti perkuliahan DPBK yang berakibat pada nilai yang kurang memuaskan. Ini terbukti dari hasil wawancara dengan beberapa mahasiswa yang telah mengambil mata kuliah DPBK. Rata-rata mahasiswa berpendapat bahwa mata kuliah DPBK masih sulit dipahami karena pemahaman terhadap model desain pembelajaran berbasis komputer dan terhadap simbol yang digunakan untuk merancang sebuah pembelajaran berbasis komputer.

Untuk saat ini hal yang relevan dengan kehidupan mahasiswa adalah penggunaan internet yang hampir digunakan setiap hari oleh mahasiswa, baik untuk jejaring sosial, mencari informasi, mengelola informasi dan menyimpan informasi. Dosen pembina sudah mencoba melakukannya, namun masih belum menunjukkan hasil yang berarti yaitu dengan penggunaan blog pribadi dalam kegiatan pembelajaran. Dengan upaya yang dosen lakukan yaitu dengan memanfaatkan internet, artinya dosen telah melakukan online learning. Pada dasarnya pembelajaran yang berbasis online belum dapat dilakukan sepenuhnya dengan kondisi mahasiswa saat ini. Oleh sebab itu, sangat diperlukan pertemuan tatap muka untuk menjaga motivasi mahasiswa dan untuk melakukan kontrol terhadap mereka.

Smaldino (2008: 181) mengungkapkan bahwa online learning dapat juga disebut dengan electronic learning yang merupakan pembelajaran yang dilakukan dengan berbantuan media berbasis komputer. Bahan pelajaran dapat diakses melalui jaringan, termasuk website, internet, intranet, CD dan DVD. Juga dijelaskan dalam kutipan di atas bahwa dengan elektronik learning atau dengan online learning tidak saja memungkinkan untuk mengakses informasi, namun juga pembelajaran memperoleh hasil yang 
memuaskan. Dan juga dapat dimanfaatkan sebagai alat pemantau kinerja dan kemajuan pebelajar.

$$
\text { Online learning }
$$

merupakan bagian dari electonic learning. Pembelajaran electronic merupakan pembelajaran yang memanfaatkan alat-alat eletronik berupa televisi, radio, telepon dan komputer. Sedangkan dalam online learning jaringan merupakan kata kunci dalam kegiatan pembelajarannya. Baik itu jaringan Local Area Network (LAN), Wide Area netrwork (WAN), wireless network, internet dan intranet. Berhubungan dengan hal itu, Munir (2009:95) juga menyebutkan bahwa online learning memerlukan pembelajaran dan pengajar berkomunikasi secara interaktif dengan memanfaatkan teknologi informasi dan komunikasi seperti media komputer dan internetnya. Berdasarkan pendapat Smaldino (2008) dan Munir (2009) dapat disimpulkan bahwa online learning merupakan pembelajaran yang terkoneksi antara satu komputer dengan komputer lainnya dengan memanfaatkan jaringan komputer untuk berinteraksi antara pembelajar dengan pendidik. Pemanfaatan jaringan diupayakan agar tercipta situasi yang membelajarkan pebelajar yang efektif, efisien dan bermakna.

Sedangkan pembelajaran yang mempertahankan pertemuan tatap muka dan dilengkapi dengan online learning lebih dikenal dengan istilah blended learning. Dalam hal ini, Smaldino (2007:44) mengemukakan bahwa "blended intructional sometimes called hybrid instruction, is mixing and macthing various instructional settings to meet the learning needs of your student".
Sesuai dengan makna kata, yaitu mencampurkan. Kemudian, Harding, Kaczynski dan Wood (2005), Blended learning merupakan pendekatan pembelajaran yang mengintegrasikan pembelajaran tradisonal tatap muka dan pembelajaran jarak jauh yang menggunakan sumber belajar online dan beragam pilihan komunikasi yang dapat digunakan oleh guru dan siswa. Pelaksanaan pembelajaran ini memungkinkan penggunaan sumber belajar online, terutama yang berbasis web, dengan tanpa meninggalkan kegiatan tatap muka. Dengan pelaksanaan blended learning, pembelajaran berlangsung lebih bermakna karena keragaman sumber belajar yang mungkin diperoleh. Selain itu, Bersin (2004) menjelaskan bahwa blended learning merupakan kombinasi berbagai media pembelajaran yang berbeda agar agar tercipta program pembelajaran yang optimum. Seperti teknologi, aktifitas dan berbagai jenis peristiwa. Berdasarkan pendapat tersebut dapat disimpukan bahwa blended itu sendiri berarti melakukan pembelajaran tatap muka didukung dengan format elektronik. Kemudian blended learning dapat diterapkan untuk mencapai tujuan yang diinginkan. Blended learning juga dapat diartikan sebagai proses pembelajaran yang memanfaatkan berbagai macam pendekatan, media, metode dan teknik. Secara sederhana dapat dikatakan bahwa blended learning adalah pembelajaran yang mengkombinasikan dan mencampur baik itu antara tatap muka, belajar mandiri serta belajar mandiri secara online, atau mencampurkan metode, media untuk mencapai tujuan pembelajaran. 
Blended

learning

dibutuhkan pada saat: a) proses belajar mengajar tidak hanya tatap muka, namun menambah waktu pembelajaran dengan memanfaatkan teknologi dunia maya. b) mempermudah dan mempercepat proses komunikasi non-stop antara pengajar dan siswa. c) mahasiswa dan dosen dapat diposisikan sebagai pihak yang belajar. Dan d) membantu proses percepatan pengajaran. Karena perkembangan teknologi informasi yang sangat pesat dewasa ini, khususnya perkembangan teknologi internet maka konsep pembelajaran jarak jauh ini juga berkembang pesat. Ciri teknologi internet yang selalu dapat diakses kapan saja, dimana saja, multiuser serta menawarkan segala kemudahannya telah menjadikan internet suatu media yang sangat tepat bagi perkembangan pendidikan jarak jauh selanjutnya. Saat ini sistem pembelajaran secara blended learning masih sangat baik diterapkan di Indonesia agar lebih dapat terkontrol.

Ranganathan, Negash, dan

Wilcox (2007:pagesite) mengemukakan bahwa ada enam klasifikasi pembelajaran eletronik yang menjadi konsep dasar terbentuknya blended learning.

a. Pertama pembelajaran tatap muka

Pembelajaran dilakukan dengan adanya kehadiran fisik pengajar yang melakukan presentasi materi secara fisik tetapi tidak melakukan komunikasi elektronik. Ini merupakan tipe kelas tatap muka di kelas secara tradisional. Pengajar atau instruktur dan orang yang belajar secara fisik hadir di kelas setiap saat penyajian materi pembelajaran. Komunikasi antara pembelajar dan pebelajar terjadi di kelas secara bersama-sama, dalam waktu dan tempat yang sama. Pembelajaran ini dimasukkan sebagai online learning karena walaupun pembelajaran lebih didominasi oleh kegiatan tatap muka, namun sudah menggunakan media elektronik sebagai kegiatan penyampaian isi pembelajaran, misalnya melalui slide PowerPoint, klip video, dan multimedia untuk memberikan penjelasan dan contoh-contoh isi pembelajaran.

b. Pembelajaran Mandiri Pembelajaran dilakukan tanpa presentasi dan kehadiran pengajar dan tanpa komunikasi elektronik, artinya pebelajar belajar sendiri. Pendekatan ini disebut sebagai belajar mandiri (self-learning). Pebelajar menerima isi/materi pembelajaran melalui belajar sendiri. Tidak ada orang yang membantu dalam format belajar mandiri, juga tidak ada komunikasi elektronik antara pebelajar dan pengajar/instruktur. Dalam format ini e-Learning pelajar biasanya menerima konten prarekaman atau mengakses arsip rekaman konten. Komunikasi antara pebelajar dan pengajar tidak dilakukan. Contoh pembelajaran tipe ini, isi disampaikan pada pebelajar menggunakan media rekaman seperti CD ROM atau DVD.

c. Pembelajaran Tidak Sinkron Pembelajaran dilakukan tanpa kehadiran pembelajar namun dilakukan degan komunikasi elektronik yang 
tidak sinkron (asynchronous). Yang dimaksud dengan tidak sinkron adalah komunikasi elektronik antara pembelajar dan pebelajar tidak dilakukan pada waktu dan tempat yang sama. Dalam format ini, pembelajar dan pebelajar tidak secara bersama-sama bertemu dalam suatu ruang yang sama. Namun, pembelajar dan pebelajar melakukan komunikasi yang dapat dilakukan melalui email dan pebelajar tidak perlu hadir secara fisik di kelas. Contoh jenis ini adalah pembelajaran eLearning dengan menggunakan ruang kelas tradisional di mana pembelajar dan pebelajar pada saat yang sama menggunakan email.

d. Pembelajaran Sinkron Pembelajaran dilakukan secara maya dan komunikasi elektronik yang sinkron (synchronous). Format ini disebut sinkron, karena pembelajar dan pebelajar selalu hadir secara real-time, walau tidak ada kehadiran fisi. Teknologi yang digunakan untuk komunikasi sinkron mencakup semua teknologi yang digunakan dalam e-Learning asynchronous selain dilakukan real-time eLearning, juga penggunaan instant messaging, chat, live audio, dan video langsung. Contoh tipe ini adalah sebuah kelas virtual dengan video audio, pembelajar dan pebelajar bertatap muka melalui video, disertai dengan chatting.

e. Blended Learning Tidak Sinkron Pembelajaran dilakukan dengan kehadiran pengajar sesekali dan komunikasi elektronik yang dikombinasi atau capuran (Blended/Hybrid-asynchronous).
Ini adalah format e-Learning blended atau hybrid dengan kehadiran pembelajar sesekali. Dalam format ini komunikasi elektronik digunakan dalam format asinkron dan sinkron. Kehadiran pembelajar yang kadang-kadang, di mana beberapa pertemuan dilakukan dengan kehadiran fisik (yaitu tatap kelas-muka) dan pada pertemuan yang dilakukan tanpa kehadiran pengajar (asynchronous). Kehadiran fisik pembelajar mirip dengan kelas tatap muka tradisional, di mana baik pembelajar maupun pebelajar secara fisik hadir di kelas. Contoh tipe ini, isi pembelajaran disampaikan kadang-kadang melalui pertemuan tatap muka dan melalui teknologi e-Learning yang dilakukan secara tidak sinkron

Berdasarkan hal itu, pembelajaran Blended dapat dilakukan dengan dua puluh lima persen melalui kehadiran pengajar dan tujuh puluh lima persen tanpa kehadiran. Ada juga yang melakukan pembelajaran dengan lima puluh persen tatap muka dan lima puluh persen melalui e-learning. Demikian pula, ada yang melakukan seratus persen kehadiran tatap muka dengan kombinasi kehadiran fisik dan maya. Meskipun tidak ada standar proporsi kehadiran tatap muka dan ketidakhadiran secara fisik, namun yang pasti dalam pembelajaran berbasis blended learning selalui mengkombinasi kegiatan tatap muka dan online learning sebagai upaya untuk memfasilitasi terjadinya belajar

METODE 
Penelitian tentang pemanfaatan blended learning pada mata kuliah Desain Pembelajaran Berbasis Komputer menggunakan metode penelitian Deskriptif Kuantitatif. Penelitian Deskriptif merupakan dasar bagi semua penelitian. Penelitian Deskriptif dapat dilakukan secara kuantitatif agar dapat dilakukan analisis statistik. Sedangkan populasi dalam penelitian ini adalah seluruh mahasiswa yang mengambil seksi mata kuliah Desain Pembelajaran Berbasis Komputer dengan sampel seksi 25669. Selanjutnya, metode analisis yang digunakan dalam penelitian ini adalah Analisis Deskriptif Persentase. Deskriptif persentase ini diolah dengan cara frekuensi dibagi dengan jumlah responden dikali 100 persen adalah sebagai:
Keterangan :

P : Persentase

f : Frekuensi

$\mathrm{N}$ : Jumlah responde

100\% : Bilangan tetap

Penghitungan deskriptif persentase ini mempunyai langkahlangkah sebagai berikut: a) Mengkoreksi jawaban kuesioner dari responden, b) Menghitung frekuensi jawaban responden, c) Jumlah responden keseluruhan adalah 53 orang dan d) Masukkan ke dalam rumus.

\section{HASIL}

Hasil belajar mahasiswa
pada mata kuliah Desain Pembelajaran berbasis komputer yang melakukan kuliah menggunakan model blended learning. Berikut data hasil belajar mahasiswa disajikan menggunakan grafik.

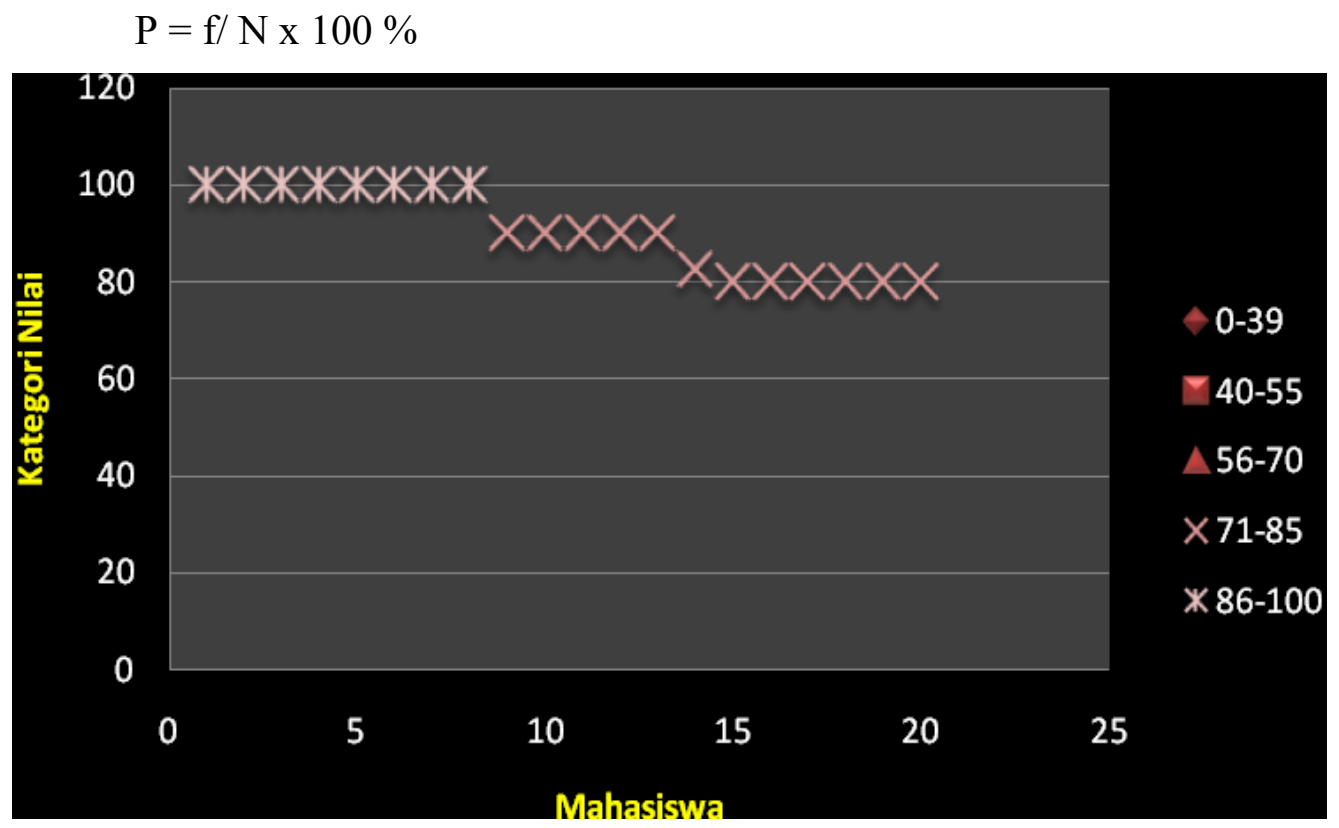

Gambar 1. Grafik Data Hasil Belajar Mahasiswa pada Mata Kuliah Desain Pembelajaran Berbasis Komputer menggunakan Model Blended Learning 
Berdasarkan patokan pada tingkat capaian 0-39, tidak efektif; tingkat capaian 40-55, kurang efektif; tingkat capaian 56-70, cukup efektif; tingkat capaian 71-85, efektif dan tingkat capaian 85-100, sangat efektif; maka diperoleh data bahwa 13 orang (65\%) mahasiswa yang mencapai nilai antara 85-100 yang berarti sangat efektif. Kemudian tujuh orang (35\%) mahasiswa berada pada tingkat capaian berkisar antara 71-85 yang berarti efektif. Namun jika dilihat dari rata-rata kelas yaitu 89,65 dapat disimpulkan bahwa model blended learning sangat efektif karena berada pada capaian 85-100.

\section{PEMBAHASAN}

Efektifitas merupakan
tingkat keberhasilan $\begin{aligned} & \text { kegiatan } \\ & \text { pembelajaran blended learning untuk } \\ & \text { menjawab pertanyaan apakah }\end{aligned}$ kegiatan pembelajaran yang telah dilakukan itu mencapai tujuan yang ditetapkan atau belum. Dalam penelitian ini, dilihat bagaimana pemanfaatan blended learning dan sejauh mana efektifitas model pembelajaran blended learning tersebut mampu membantu mahasiswa untuk memahami materi mata kuliah dan membantu mencapai kompetensi yang diinginkan. Jika ketercapaian tujuan pembelajaran berkisar antara 0-39 maka model pembelajaran blended learning tidak efektif dalam membantu mahasiswa untuk memahami materi mata kuliah dan membantu mencapai kompetensi yang diinginkan, jika berkisar antara 40-55 maka model pembelajaran blended learning kurang efektif membantu mahasiswa untuk memahami materi mata kuliah dan membantu mencapai kompetensi yang diinginkan, jika berkisar antara capaian 56-70 maka model pembelajaran blended learning cukup efektif membantu mahasiswa untuk memahami materi mata kuliah dan membantu mencapai kompetensi yang diinginkan, jika hasil penilaian mencapai 71-85 maka model pembelajaran blended learning efektif membantu mahasiswa untuk memahami materi mata kuliah dan membantu mencapai kompetensi yang diinginkan dan jika capaian 85100 maka model pembelajaran blended learning sangat efektif membantu mahasiswa untuk memahami materi mata kuliah dan membantu mencapai kompetensi yang diinginkan. Hal ini juga berdasarkan pendapat Akker (1999) bahwa keefektifan mengacu pada tingkatan pengalaman dan hasil intervensi tujuan yang dimaksud. Ini berarti bahwa keefektifan suatu model pembelajaran dilihat dari kualitas hasil belajar. Berdasarkan hasil belajar mahasiswa tersebut ternyata model blended learning efektif dalam mencapai tujuan pembelajaran yang telah ditetapkan sebelumnya.

Berdasarkan hasil penelitian bagaimana pemanfaatan dan keefektifan model blended learning dalam membantu mahasiswa untuk memahami materi mata kuliah dan membantu mencapai kompetensi yang diinginkan karena pemanfaatan blended learning sesuai dengan situasi yang menudukung untuk dilakukan kombinasi. Blended learning dibutuhkan pada saat situasi yang ada menuntut diadakannya kombinasi atau mencampurkan, yaitu tersedianya berbagai metode media, dan teknik untuk mencapai tujuan pembelajaran. Misalnya ketika pembelajaran jarak jauh tidak begitu dibutuhkan maka dibutuhkan pembelajaran tatap muka, dan 
sebaliknya ketika dibutuhkan online learning maka dilakukan pembelajaran menggunakan jaringan. Proses pembelajaran blended learning ini dibutuhkan pada mahasiswa yang membutuhkan penambahan dan pengkombinasian dalam pembelajaran.

Kemudian, keefektifan

blended learning juga berdasarkan pada tujuan dari blended learning itu sendiri, yaitu a) membantu mahasiswa untuk berkembang lebih baik di dalam proses belajar, sesuai dengan gaya belajar dan preferensi dalam belajar. b) menyediakan peluang yang praktis realistis bagi dosen dan mahasiswa untuk pembelajaran secara mandiri, bermanfaat, dan terus berkembang. c) peningkatan penjadwalan fleksibilitas bagi mahasiswa, dengan menggabungkan aspek terbaik dari tatap muka dan online learning. Kelas tatap muka dapat digunakan untuk melibatkan para mahasiswa dalam pengalaman interaktif. Sedangkan porsi online memberikan mahasiswa dengan konten multimedia yang kaya akan pengetahuan pada setiap saat, dan di mana saja selama pemelajar memiliki akses internet.

Selanjutnya, keefektifan model blended learning dalam membantu mahasiswa untuk memahami materi mata kuliah dan membantu mencapai kompetensi yang diinginkan juga didukung oleh kelebihan dilakukannya blended learning itu sendiri. Misalnya pembelajaran terjadi secara mandiri dan konvensional, yang keduanya memiliki kelebihan yang dapat saling melengkapi, pembelajaran lebih efektif dan efisien dan blended learning dapat meningkatkan aksesbiltas. Dengan adanya blended learning maka mahasiswa semakin mudah dalam mengakses materi pembelajaran.

Berdasarkan kajian teori dan kajian-kajian penelitian, blended learning merupakan suatu cara belajar yang berasal dari pertimbangan-pertimbangan dalam menyempurnakan sistem belajar online learning. Dari penelitian yang ada, kendala terbesar online learning adalah proses interaksi langsung antara mahasiswa dan dosen. Bagaimanapun belajar merupakan proses dua arah. Mahasiswa memerlukan feedback dari dosen dan sebaliknya dosen juga memerlukan feedback dari mahasiswanya. Dengan cara ini akan didapat hasil belajar yang lebih efektif dan tepat sasaran.

Hal ini menjawab mengapa program e-learning tidak selalu mendapat hasil memuaskan. Seringkali materi sudah banyak dan tersedia dengan lengkap. Orang juga bisa belajar kapan saja dan di mana saja, asal terkoneksi lewat jaringan nirkabel. Namun tetap saja tingkat penggunaan materi-materi e-learning tersebut tergolong rendah. secara sederhana dapat dikatakan seseorang butuh teman dan butuh feedback langsung. Sama seperti yang kita rasakan dalam pembelajaran konvensional di ruang kelas.

Selain itu online learning menciptakan kesan kesendirian sehingga seseorang tidak bisa bertahan lama dalam belajar. Dalam setengah jam, seseorang sudah malas dan tidak terlalu termotivasi untuk melanjutkan pembelajarannya. Bukan karena materinya tidak bagus atau sistem online dari materi yang disajikan kurang interaktif, melainkan orang merasa sedang sendiri dan merasa butuh dengan orang lain. Belajar secara mandiri 
dibutuhkan motivasi dan kesadaran tinggi dari pembelajarnya. Berdasarkan pertimbangan permasalah tersebut, pembelajaran yang lebih efektif digunakan adalah blended learning, dimana mahasiswa dapat belajar secara mandiri dan secara konvensional, keduanya menawarkan kelebihan-kelebihan yang dapat saling melengkapi.

Keefektifan model blended learning juga didukung oleh komunikasi antara dosen dan mahasiswa terjadi di kelas secara bersama-sama, dalam waktu dan tempat yang sama serta komunikasi melalui online learning. Pembelajaran ini dimasukkan sebagai online learning karena walaupun pembelajaran lebih didominasi oleh kegiatan tatap muka, namun sudah menggunakan media elektronik sebagai kegiatan penyampaian isi pembelajaran, misalnya melalui slide PowerPoint, klip video, dan multimedia untuk memberikan penjelasan dan contohcontoh isi pembelajaran.

Dengan begitu, peraturan Pemerintah nomor 32 tahun 2013 tentang standar proses yang menekankan proses pembelajaran dilakukan secara interaktif, inspiratif, menyenangkan, menantang, memotivasi peserta didik untuk berpartisipasi aktid serta memberikan ruang cukup bagi prakarsa, kreativitas dan kemandian sesuai dengan bakat, mengutamakan berfikir ilmiah, keterampilan proses dengan pendekatan sains dan menggunakan teori konstruktivisme dapat terwujud. Kontruktivisme menyatakan bahwa belajar adalah aktif dalam konteks proses penyusunan pengetahuan. Pengetahuan disusun berdasarkan pengalaman pribadi dan hipotesis dari lingkungan. Mahasiswa terusmenerus menguji hipotesis ini melalui negosiasi sosial. Setiap orang memiliki interpretasi dan proses konstruksi pengetahuan yang berbeda. Kontruktivisme menganggap bahwa semua pengetahuan dibangun dari pengetahuan mahasiswa sebelumnya.

\section{KESIMPULAN}

Berdasarkan hasil penelitian dan pembahasan penelitian ini maka dapat diambil kesimpulan bahwa pemanfaatan model blended learning dalam membantu mahasiswa untuk memahami materi mata kuliah dan membantu mencapai kompetensi yang diinginkan didukung oleh situasi yang menudukung untuk dilakukan kombinasi. Blended learning dibutuhkan pada saat situasi yang ada menuntut diadakannya kombinasi atau mencampurkan, yaitu tersedianya berbagai metode media, dan teknik untuk mencapai tujuan pembelajaran serta kebutuhan mahasiswa itu sendiri. Ketika pembelajaran online tidak begitu dibutuhkan maka dibutuhkan pembelajaran tatap muka, dan sebaliknya ketika dibutuhkan online learning maka dilakukan pembelajaran menggunakan jaringan. Selanjutnya, berdasarkan hasil penelitian model blended learning efektif dalam membantu mahasiswa untuk memahami materi mata kuliah dan membantu mencapai kompetensi.

\section{IMPLIKASI}

Berdasarkan kesimpulan dan pembahasan di atas, maka rekomenasi yang peneliti ajukan beranjak dari kekurangan model blended learning itu sendiri. a) 
Dalam pembelajaran blended, media yang dibutuhkan sangat beragam, sehingga sulit diterima.

apkan apabila sarana dan prasarana tidak mendukung. Oleh sebab itu, ketika ingin menerapkan model blended learning, perlu dipersiapkan media-media yang relevan untuk mencapai tujuan pembelajaran. b) Selanjutnya, tidak meratanya fasilitas yang dimiliki mahasiswa seperti komputer dan akses internet. Padahal dalam blended learning diperlukan akses internet yang memadai, apabila jaringan kurang memadai akan menyulitkan mahasiswa dalam mengikuti pembelajaran mandiri via online. Oleh sebab itu, perlu analisis kelayakan sebelum dilakukan blended learning. dan c) kurangnya pengetahuan masyarakat terhadap penggunaan teknologi perlu ditingkatkan ketika ingin menerapkan blended learning.

\section{DAFTAR BACAAN}

Akker, Jan Van Den. 1999. Design Approaches and Tools in Education and Training. Dordrecht:Kluwer Academic Publisher

Bersin, Josh. 2004. The Blended Learning Book; Best Practices, Proven Methodologies and Lessons Learned. United Stated: John Wiley \& Sona, Inc.

Harding, Kaczynski dan Wood (2005) science.uniserve.edu.au/pubs/ .../2005Harding. $p d f$

Munir. 2009. Pembelajaran Jarak Jauh Berbasis Teknologi Informasi dan Komunikasi. Bandung: ALFABETA

Permendiknas No. 41 Tahun 2007 tentang Standar Proses
Peraturan Pemerintah nomor 32 tahun 2013 tentang standar proses

Smaldino, Sharon E, dkk. 2007. Instructional Technology And Media For Learning Ninth edition. New Jersey Columbus, Ohio: PEARSON Merrill Prentice Hall

Ranganathan, Negash, dan Wilcox (2007:pagesite) http://www.sciepub.com /reference/38310 